\title{
Involvement of adrenoceptors, dopamine receptors and AMPA receptors in antidepressant-like action of 7-0-ethylfangchinoline in mice
}

\author{
Zhao-fu SHENG, Xiang-yu CUI, Su-ying CUI, Bin YU, Xue-qiong ZHANG, Sheng-jie LI, Qing CAO, Yuan-li HUANG, Ya-ping XU, \\ Jin-zhi SONG, Hui DING, Zhi-ge LIN, Guang YANG, Yong-he ZHANG* \\ Department of Pharmacology, School of Basic Medical Science, Peking University, Beijing 100191, China
}

\begin{abstract}
Aim: 7-O-ethylfangchinoline (YH-200) is a bisbenzylisoquinoline derivative. The aim of this study was to investigate the antidepressantlike action and underlying mechanisms of $\mathrm{YH}-200$ in mice.

Methods: Mice were treated with YH-200 (15, 30, and $60 \mathrm{mg} / \mathrm{kg}$, ig) or tetrandrine (30 and $60 \mathrm{mg} / \mathrm{kg}$, ig) before conducting forced swimming test (FST), tail suspension test (TST), or open field test (OFT).

Results: YH-200 $(60 \mathrm{mg} / \mathrm{kg})$ significantly decreased the immobility time in both FST and TST, and prolonged the latency to immobility in FST. YH-200 $(60 \mathrm{mg} / \mathrm{kg})$ was more potent than the natural bisbenzylisoquinoline alkaloid tetrandrine $(60 \mathrm{mg} / \mathrm{kg})$ in FST. Pretreatment with $\alpha_{1}$-adrenoceptor antagonist prazosin (1 mg/kg), $\beta$-adrenoceptor antagonist propranolol $\left(2 \mathrm{mg} / \mathrm{kg}\right.$ ), dopamine $\mathrm{D}_{1} / \mathrm{D}_{5}$ receptor antagonist SCH23390 $(0.05 \mathrm{mg} / \mathrm{kg})$, dopamine $\mathrm{D}_{2} / \mathrm{D}_{3}$ receptor antagonist haloperidol $(0.2 \mathrm{mg} / \mathrm{kg})$ or AMPA receptor antagonist NBQX $(10 \mathrm{mg} / \mathrm{kg})$ prevented the antidepressant-like action of YH-200 $(60 \mathrm{mg} / \mathrm{kg})$ in FST. In contrast, pretreatment with $\alpha_{2}$ adrenoceptor antagonist yohimbine $(1 \mathrm{mg} / \mathrm{kg})$ augmented the antidepressant-like action of YH-200 (30 mg/kg) in FST. Chronic administration of $\mathrm{YH}-200$ (30 and $60 \mathrm{mg} / \mathrm{kg}$ for $14 \mathrm{~d}$ ) did not produce drug tolerance; instead its antidepressant-like action was strengthened. Chronic administration of $\mathrm{YH}-200$ did not affect the body weight of mice compared to control mice.

Conclusion: $\mathrm{YH}-200$ exerts its antidepressant-like action in mice via acting at multi-targets, including $\alpha_{1}, \alpha_{2}$ and $\beta$-adrenoceptors, $D_{1} / D_{5}$ and $D_{2} / D_{3}$ receptors, as well as AMPA receptors.
\end{abstract}

Keywords: depression; antidepressant; 7-O-ethylfangchinoline; tetrandrine; adrenoceptor; dopamine receptor; AMPA receptor; forced swimming test; tail suspension test

Acta Pharmacologica Sinica (2015) 36: 949-956; doi: 10.1038/aps.2015.57

\section{Introduction}

Studies have demonstrated that numerous neural pathways are involved in the pathophysiology of depression ${ }^{[1]}$. The treatment of depression is one of the most challenging issues in contemporary psychiatry. Most of the currently available antidepressants harness monoaminergic mechanisms. The conventional and available antidepressants can provide a complete remission for only $50 \%-60 \%$ of the treated individuals ${ }^{[2]}$, and it often takes more than 5-8 weeks for the patients to respond to the treatment. In addition, there is the presence of adverse effects ${ }^{[3]}$. Thus, pursuing new pharmacotherapy with elevated efficacy and fewer adverse side-effects is an utmost clinical need. Multi-targets have been

\footnotetext{
* To whom correspondence should be addressed.

E-mail zhyh@hsc.pku.edu.cn

Received 2015-03-27 Accepted 2015-05-26
}

emphasized as new antidepressant therapeutic strategies ${ }^{[4,5]}$. The association of a clinically characterized antidepressant mechanism with a non-monoaminergic component of activity is an attractive strategy. For example, agomelatine (a melatonin agonist/5- $\mathrm{HT}_{2 \mathrm{C}}$ antagonist) has clinically proven activity in major depression ${ }^{[6]}$.

It has been assumed that some bisbenzylisoquinoline (BBI) derivatives may possess potential antidepressant activity ${ }^{[7]}$. The total tertiary alkaloid fraction or hydroalcoholic leaf extract (containing warifteine, a type of BBI alkaloid) from Cissampelos sympodialis reduced the total immobility time in a forced swimming test (FST) and demonstrated an antidepressant effect ${ }^{[8]}$. Therefore, we hypothesized that 7-O-ethylfangchinoline (YH-200, Figure 1), a BBI derivative, may also possess antidepressant-like activity. In this study, we investigated the antidepressant-like effect of $\mathrm{YH}-200$ in a mouse FST and tail suspension test (TST) and evaluated its possible mechanisms. 


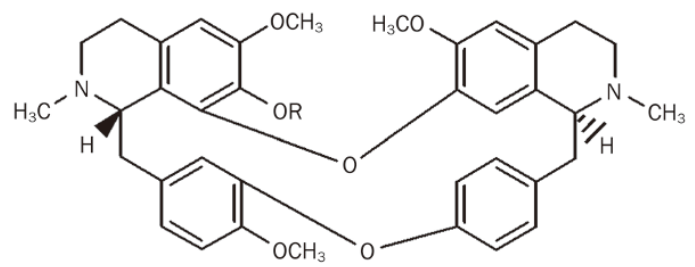

Figure 1. The structure of tetrandrine and 7-O-ethylfangchinoline ( $\mathrm{YH}-2 \mathrm{OO})$. Tetrandrine: $\mathrm{R}=\mathrm{CH}_{3}$; $\mathrm{YH}-2 \mathrm{OO}: \mathrm{R}=\mathrm{CH}_{2} \mathrm{CH}_{3}$.

\section{Materials and methods Animals}

Male ICR mice $(n=451 ; 20-25 \mathrm{~g}$, purchased from the Animal Center of Peking University, Beijing, China) were used. The mice were maintained at $22-25^{\circ} \mathrm{C}$ with free access to water and food under a 12-h light/12-h dark cycle (lights on at 9:00 AM). All manipulations were carried out from 1:00 PM to 5:00 PM. All experiments were conducted in accordance with the European Community guidelines for the use of experimental animals and were approved by the Peking University Committee on Animal Care and Use.

\section{Drugs and treatment}

Tetrandrine and fangchinoline were isolated from the roots of the creeper Stephania tetrandrae S Moore of the Menispermaceae family. YH-200 was prepared from fangchinoline ethylation. Analysis of the ${ }^{1} \mathrm{HNMR}$ and ${ }^{13} \mathrm{CNMR}$ spectra showed analytical and spectroscopic data that were in full agreement with these assigned structures. The chemical purities of these compounds $(99.9 \%)$ were determined by highperformance liquid chromatography. Prazosin hydrochloride (an $\mathrm{a}_{1}$-adrenoceptor antagonist), yohimbine hydrochloride (an $\mathrm{a}_{2}$-adrenoceptor antagonist), propranolol (a $\beta$-adrenoceptor antagonist), haloperidol (a dopamine $\mathrm{D}_{2} / \mathrm{D}_{3}$ receptor antagonist), $R(+)$-7-chloro-8-hydroxy-3-methyl-1-phenyl-2,3,4,5tetrahydro-1H-3-benzazepinehydrochloride (SCH23390, a dopamine $D_{1} / D_{5}$ receptor antagonist) and imipramine were purchased from Sigma-Aldrich Co (St Louis, MO, USA); NBQX (an a-amino-3-hydroxy-5-methyl-4-isoxazole-propionic acid (AMPA) receptor antagonist) was purchased from Tocris Cookson Ltd (Bristol, UK). For administration, YH-200 and imipramine were dissolved in distilled water; haloperidol was dissolved in 5\% ethanol/physiological saline. Other drugs were dissolved in saline. Acute and repeated $(14 \mathrm{~d})$ treatments were performed during the artificial lighting period. All drugs were administered in a constant volume of $10 \mathrm{~mL} / \mathrm{kg}$ body weight.

In the experiments designed to verify the antidepressantlike effects of $\mathrm{YH}-200$, mice were treated with vehicle, $\mathrm{YH}-200$ $(15,30$, and $60 \mathrm{mg} / \mathrm{kg}$, ig) or imipramine $(40 \mathrm{mg} / \mathrm{kg}$, ig) as a positive control $60 \mathrm{~min}$ before the TST or FST. We also compared the effects of $\mathrm{YH}-200$ (30 and $60 \mathrm{mg} / \mathrm{kg}$, ig) with that of tetrandrine (30 and $60 \mathrm{mg} / \mathrm{kg}$, ig) in the FST, and mice were treated in an identical manner. To further investigate whether the immobility time in the FST was related to alterations in locomotor activity, mice were subjected to an open field test (OFT) $60 \mathrm{~min}$ after YH-200 (15-60 mg/kg, ig) treatment. Different sets of mice were used in the TST, FST, OFT, and monoamines assay, and each mouse was used for only once.

In the experiments to investigate the drug interaction, mice were pre-treated with prazosin $(1 \mathrm{mg} / \mathrm{kg}, \mathrm{ip})$, yohimbine (1 mg/kg, ip), propranolol (2 mg/kg, ip), SCH23390 (0.05 $\mathrm{mg} / \mathrm{kg}$, sc), haloperidol (0.2 mg/kg, ip) and NBQX (10 mg/kg, ip), respectively, and 15 min later animals received $\mathrm{YH}-200$ (30 or $60 \mathrm{mg} / \mathrm{kg}$, ig). The FST were performed after $60 \mathrm{~min}$ of YH-200 administration.

To investigate whether the drug resistance was developed, mice were repeatedly treated with YH-200 (30 and $60 \mathrm{mg} \cdot \mathrm{kg}^{-1} \cdot \mathrm{d}^{-1}$, ig) for $14 \mathrm{~d}$. Sixty minutes after treatment on the last day, mice were subjected to the FST for 6 min. Body weight was measured daily before YH-200 administration.

\section{Forced swimming test}

The test was conducted using a slightly modified method described by Porsolt et al ${ }^{[9,10]}$. Assays were conducted $24 \mathrm{~h}$ after a 15-min pretest session by placing the mice in transparent cylinders filled with water $\left(25^{\circ} \mathrm{C}\right.$; diameter $10 \mathrm{~cm}$, height $25 \mathrm{~cm})$. The total duration of immobility during a 6-min test and the latency to the first bout of immobility were scored (DigBehv-FS, Shanghai Jiliang Software Technology Co, Ltd, Shanghai, China). Each mouse was judged to be immobile when it ceased struggling and remained floating motionless in the water, making only those movements that were necessary to keep its head above water. After the experiment, the mouse was removed from the cylinder, dried with a towel, and placed in its home cage to be dried under a heat lamp. The water in the cylinder was changed for each mouse.

\section{Tail suspension test}

The method is based on the fact that mice develop an immobile posture when they are suspended by their tail, which is an inescapable, short-term stressor ${ }^{[11]}$. Briefly, mice were acoustically and visually isolated and then suspended $50 \mathrm{~cm}$ above the floor by adhesive tape placed approximately $1 \mathrm{~cm}$ from the tip of the tail. The immobility time was recorded for $6 \mathrm{~min}$. Mice were considered to be immobile only when they hung passively and were completely motionless.

\section{Open field test (OFT)}

As described previously ${ }^{[12]}$, locomotor activity was recorded and analyzed using a Mouse and Rat Spontaneous Activity Video Analysis System (JLBehv-LAG-4, Shanghai Jiliang Software Technology Co, Ltd). There were 4 adjacent enclosures $(25 \mathrm{~cm} \times 25 \mathrm{~cm} \times 50 \mathrm{~cm}$ each) with video cameras on the ceiling. The activity of mice (separated in each enclosure) was recorded simultaneously for $6 \mathrm{~min}$. Each enclosure was arbitrarily divided into a central region $(12.5 \mathrm{~cm} \times 12.5 \mathrm{~cm})$ and peripheral regions. The locomotor tracks in the open field were continuously recorded by a video camera and analyzed using a computer. After each testing session, the enclosures were thoroughly cleaned with $10 \%$ ethanol. 


\section{HPLC-ECD analysis of monoamines}

To investigate neurochemical mechanisms, 60 min after YH-200 (15-60 mg/kg, ig) administration, the mice were decapitated. The hippocampus, prefrontal cortex, striatum and hypothalamus of the mice were separated rapidly and stored at $-80^{\circ} \mathrm{C}$ for the monoamines assay. Brain tissues were then homogenized by ultrasound in $0.2 \mathrm{~mol} / \mathrm{L}$ perchloric acid homogenate. The mixture was centrifuged twice $(18000 \times g)$ for $50 \mathrm{~min}$ at $4^{\circ} \mathrm{C}$. Levels of norepinephrine (NE), dopamine (DA) and 3,4-dihydroxyphenylacetic acid (DOPAC) were detected by HPLC-ECD (Dionex UltiMate 3000, Thermo Scientific, Santa Clara, CA, USA) using a C18 reverse phase column (3.0 mm id×75 mm; Capcell Pak C18 MG S3, Shiseido, Japan). The mobile phase of the HPLC system contained $0.85 \mathrm{mmol} / \mathrm{L}$ sodium octylsulfate, $0.5 \mathrm{mmol} / \mathrm{L}$ EDTA, and $0.1 \mathrm{mmol} / \mathrm{L}$ $\mathrm{NaH}_{2} \mathrm{PO}_{4}$ in $11 \%$ methanol at $\mathrm{pH} 3.25$. The flow-rate was 0.6 $\mathrm{mL} / \mathrm{min}$. The electrochemical detector was set at $200 \mathrm{MV}$ for the oxidizing potential and $-175 \mathrm{MV}$ for the reducing potential. The injection volume was $20 \mu \mathrm{L}^{[13]}$.

\section{Statistical analysis}

All values are expressed as the mean \pm SEM. The differences between groups were analyzed by a two-way or one-way analysis of variance (ANOVA) followed by Student-NewmanKeul's test as a post hoc comparison. Probability values less than $0.05(P<0.05)$ were considered statistically significant. All statistical procedures were carried out using SAS Software (version 9.1, SAS Institute Inc).

\section{Results}

YH-200 exhibited an anti-immobility effect without the influence of locomotor activity

As shown in Figure 2, YH-200 (60 mg/kg, ig) significantly decreased the immobility time of mice in the FST $\left(F_{(4,45)}=9.94\right.$, $P<0.0001$; Figure 2A) and TST $\left(F_{(4,30)}=9.07, P<0.0001\right.$; Figure 2B). The OFT showed that YH-200 (15-60 mg/kg, ig) did not influence the locomotor activity of mice (total distance: $F_{(3,36)}=0.11$, $P=0.9560$; distance in peripheral area: $F_{(3,36)}=0.08, P=0.9721$; distance in central area: $F_{(3,36)}=0.17, P=0.9140$; mean movement speed: $F_{(3,36)}=0.11, P=0.9560$; Figures $2 \mathrm{C}$ and $\left.2 \mathrm{D}\right)$. In the comparison test, $\mathrm{YH}-200(60 \mathrm{mg} / \mathrm{kg}$, ig) showed the same potency by prolonging the latency to immobility $\left(F_{(4,45)}=8.75, P<0.0001\right.$; Figure $3 \mathrm{~A})$ and shortening the immobility time $\left(F_{(4,45)}=22.96\right.$, $P<0.0001$; Figure 3B) in the FST. The antidepressant-like activity of $\mathrm{YH}-200$ was more potent than its derivative tetrandrine (Figure 3), the naturally occurring bisbenzylisoquinoline alkaloid.

\section{Antidepressant-like effect of $\mathrm{YH}-200$ involved multi-receptors} Role of the adrenergic $\alpha_{1}, \alpha_{2}$, or $\beta$ receptor in the antidepressantlike activity of $\mathrm{YH}-200$

As shown in Figure 4A, a two-way ANOVA revealed significant differences in pre-treatment (saline or prazosin; $F_{(1,28)}=54.18, P<0.0001$ ), treatment (vehicle or $\mathrm{YH}-200$; $\left.F_{(1,28)}=77.38, P<0.0001\right)$, and the pre-treatment $\times$ treatment interaction $\left(F_{(1,28)}=42.10, P<0.0001\right)$ in immobility times in the FST.
Post hoc analysis indicated that pre-treating the mice with prazosin $(1 \mathrm{mg} / \mathrm{kg}$, ip) significantly abrogated the decrease in the immobility elicited by $\mathrm{YH}-200(60 \mathrm{mg} / \mathrm{kg}$, ig) in the FST.

As shown in Figure 4B, a two-way ANOVA revealed significant differences in pre-treatment (saline or yohimbine; $F_{(1,28)}=17.09, P=0.0003$ ), treatment (vehicle or $\mathrm{YH}-200$; $\left.F_{(1,28)}=15.34, P=0.0005\right)$, and the pre-treatment $\times$ treatment interaction $\left(F_{(1,28)}=5.23, P=0.03\right)$ in immobility times in the FST. Post hoc analysis indicated that the antidepressant-like effect of a sub-threshold dose of $\mathrm{YH}-200(30 \mathrm{mg} / \mathrm{kg}$, ig) was significantly enhanced by pre-treatment with yohimbine $(1 \mathrm{mg} / \mathrm{kg}, \mathrm{ip})$.

As shown in Figure 4C, a two-way ANOVA revealed significant
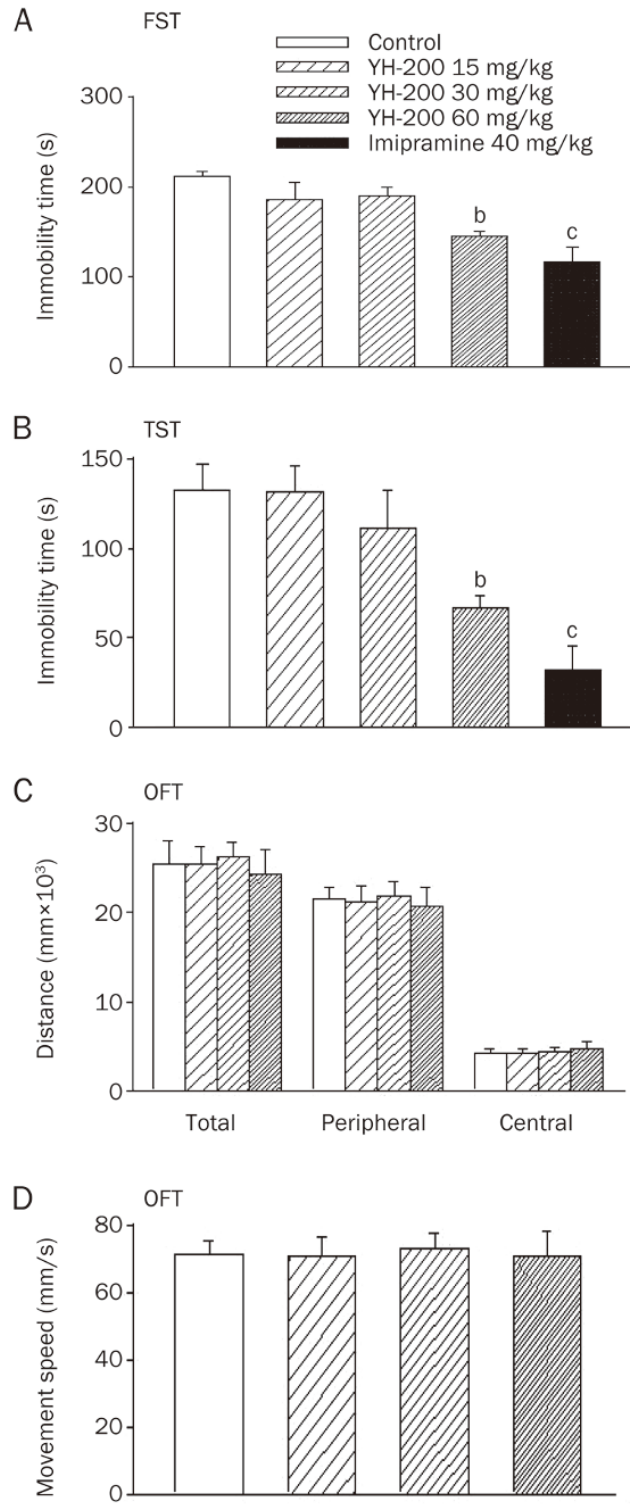

Figure 2. Effects of acute administration of $\mathrm{YH}-200$ on immobility times in the forced swimming test (FST) (A, $n=10 /$ group) and tail suspension test (TST) (B, $n=7 /$ group). ( $\mathrm{C}$ and D) Locomotor activity in the open field test (OFT) of mice treated with $\mathrm{YH}-200$. $n=10 /$ group. Values are expressed as the mean \pm SEM. ${ }^{b} P<0.05,{ }^{C} P<0.01$ vs control group. 

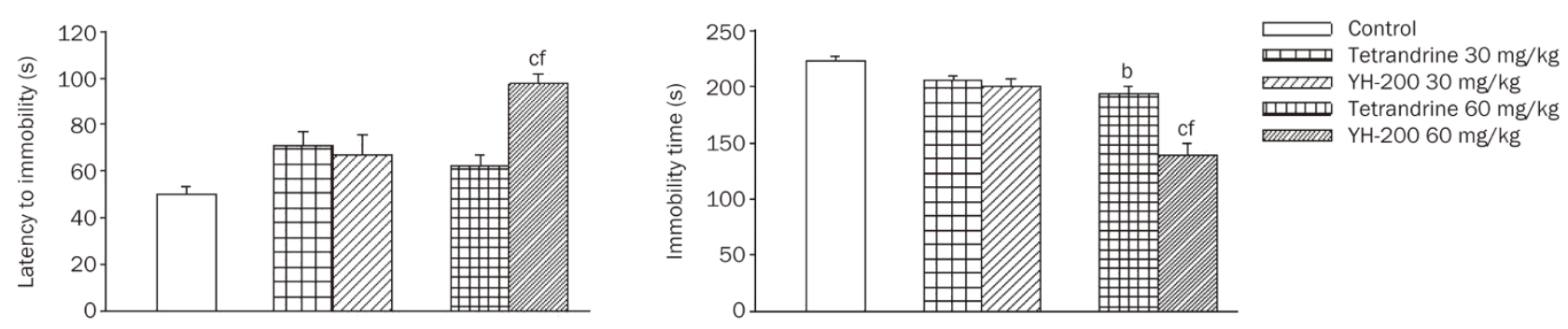

Figure 3. Antidepressant-like effects of $\mathrm{YH}-200$ compared with that of tetrandrine in the FST. Values are expressed as the mean \pm SEM. ${ }^{\mathrm{b}} P<0.05$, ${ }^{c} P<0.01$ vs control. ${ }^{f} P<0.01$ vs tetrandrine group at the same dose. $n=10 /$ group.
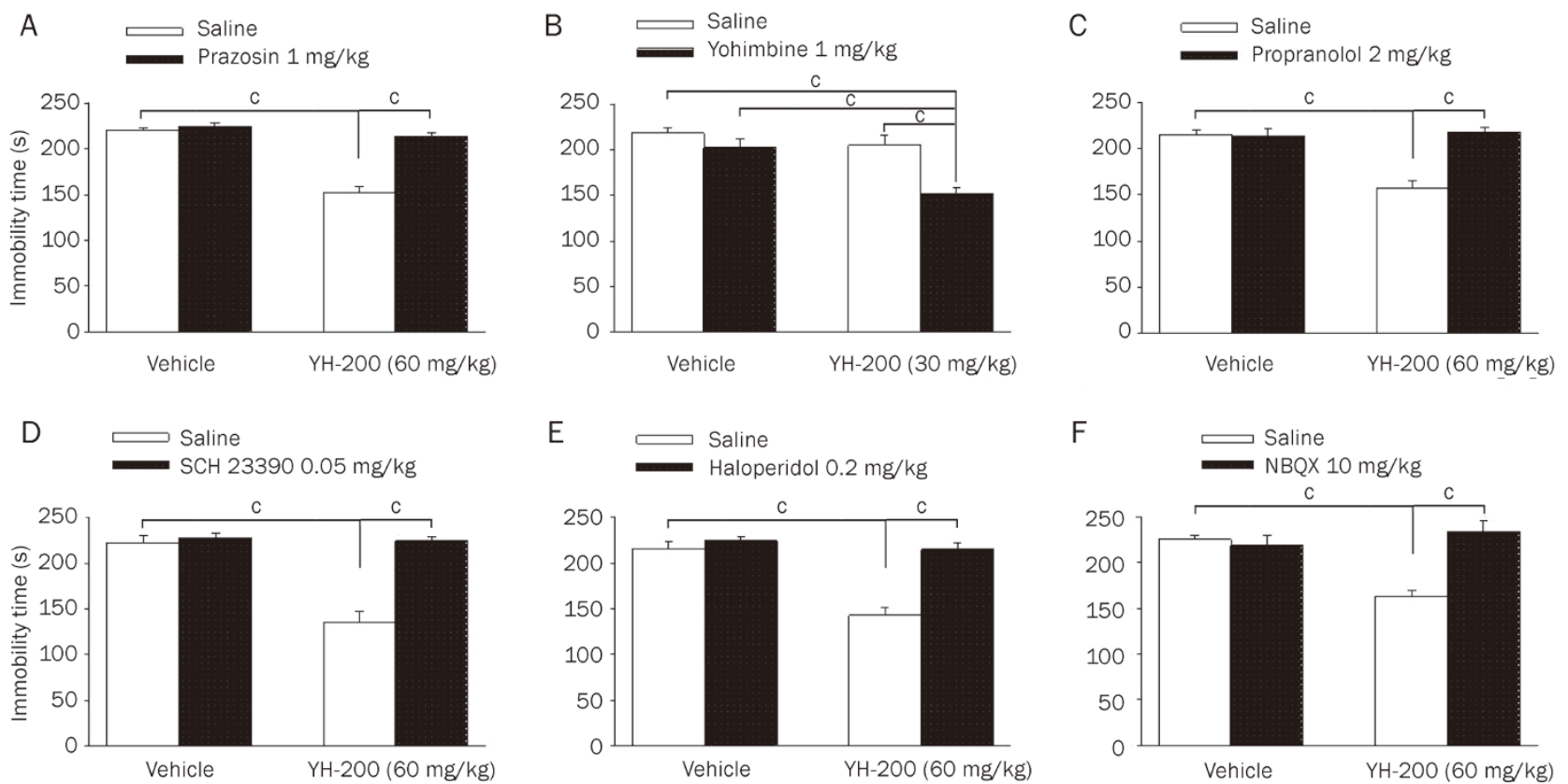

Figure 4. Effects of pretreatment with prazosin (A), yohimbine (B), propranolol (C), SCH23390 (D), haloperidol (E), or NBQX (F) on the anti-immobility effect of $\mathrm{YH}-200$ in the mouse FST. $n=8-9 /$ group. The combined administration of subeffective dose of $\mathrm{YH}-200$ and yohimbine showed synergistic antidepressant-like effect in the mouse FST. Values are expressed as mean \pm SEM. ${ }^{\mathrm{c}} P<0.01$.

differences in pre-treatment (saline or propranolol; $F_{(1,28)}=20.50$, $P=0.0001$ ), treatment (vehicle or $\mathrm{YH}-200 ; F_{(1,28)}=16.86, P=0.0003$ ), and the pretreatment $\times$ treatment interaction $\left(F_{(1,28)}=21.65\right.$, $P<0.0001)$ in immobility times in the FST. Post hoc analyses indicated that the antidepressant-like effect of YH-200 $(60 \mathrm{mg} / \mathrm{kg}$, ig) was significantly attenuated by pre-treatment with propranolol ( $2 \mathrm{mg} / \mathrm{kg}$, ip).

Role of the dopamine $D_{1} / D_{5}$ and $D_{2} / D_{3}$ receptors in the antidepressant-like activity of $\mathrm{YH}-200$

As shown in Figure 4D, a two-way ANOVA revealed significant differences in pre-treatment (vehicle or SCH 23390; $F_{(1,28)}=35.30, P<0.0001$ ), treatment (vehicle or YH-200; $\left.F_{(1,28)}=32.36, P<0.0001\right)$, and the pre-treatment $\times$ treatment interaction $\left(F_{(1,28)}=28.77, P<0.0001\right)$ in immobility times in the FST. Post hoc analyses indicated that pre-treating with $\mathrm{SCH} 23390$ $(0.05 \mathrm{mg} / \mathrm{kg}, \mathrm{sc})$ significantly abrogated the decrease in immo- bility times elicited by YH-200 (60 mg/kg, ig) in the FST.

As shown in Figure 4E, a two-way ANOVA revealed significant differences in pre-treatment (saline or haloperidol; $F_{(1,32)}=35.48, P<0.0001$ ), treatment (vehicle or YH-200; $\left.F_{(1,32)}=36.96, P<0.0001\right)$, and the pre-treatment $\times$ treatment interaction $\left(F_{(1,32)}=22.05, P<0.0001\right)$ in immobility times in the FST. Post hoc analyses indicated that the antidepressant-like effect of YH-200 (60 mg/kg, ig) was significantly attenuated by pretreatment with haloperidol $(0.2 \mathrm{mg} / \mathrm{kg}$, ip).

Role of the AMPA receptor in the antidepressant-like activity of $\mathrm{YH}-200$

As shown in Figure 4F, a two-way ANOVA revealed significant differences in pre-treatment (saline or NBQX; $F_{(1,28)}=11.64$, $P=0.0020$ ), treatment (vehicle or $\mathrm{YH}-200 ; F_{(1,28)}=6.50, P=0.0166$ ), and the pre-treatment $\times$ treatment interaction $\left(F_{(1,28)}=16.72\right.$, $P=0.0003)$ in immobility times in the FST. Post hoc analyses 
indicated that the antidepressant-like effect of YH-200 (60 $\mathrm{mg} / \mathrm{kg}$, ig) was significantly attenuated by pre-treatment with NBQX (10 mg/kg, ip).

Effects of YH-200 on the concentration of NE, DA, and DOPAC in the hippocampus, prefrontal cortex, striatum and hypothalamus As shown in Table 1, YH-200 (30 and $60 \mathrm{mg} / \mathrm{kg}$, ig) or imipramine $(40 \mathrm{mg} / \mathrm{kg}$, ig) significantly increased NE levels in the prefrontal cortex compared to the control group $(P<0.01$ for $Y H-20030 \mathrm{mg} / \mathrm{kg} ; P<0.01$ for $Y H-20060 \mathrm{mg} / \mathrm{kg}$; $P<0.01$ for imipramine $40 \mathrm{mg} / \mathrm{kg}$ ), and no significant differences in the DA and DOPAC levels were observed between the groups. In the striatum, $\mathrm{YH}-200(60 \mathrm{mg} / \mathrm{kg}$, ig) and imipramine (40 $\mathrm{mg} / \mathrm{kg}$, ig) significantly increased the NE levels $(P<0.05$ for

Table 1. Effects of $\mathrm{YH}-200$ on the concentrations of NE, DA, DOPAC. Values are expressed as the mean \pm SEM. Data were analyzed by one-way ANOVA followed by the SNK test.

\begin{tabular}{|c|c|c|c|c|}
\hline \multirow{2}{*}{\multicolumn{2}{|c|}{ Group }} & \multicolumn{3}{|c|}{ Concentration (ng/g wet tissue) } \\
\hline & & $\mathrm{NE}$ & DA & DOPAC \\
\hline \multicolumn{5}{|c|}{ Prefrontal cortex } \\
\hline \multicolumn{2}{|l|}{ Vehicle } & $372.0 \pm 18.7$ & $79.3 \pm 26.6$ & $88.5 \pm 19.4$ \\
\hline \multirow[t]{3}{*}{ YH-200 } & $15 \mathrm{mg} / \mathrm{kg}$ & $393.0 \pm 21.4$ & $55.4 \pm 24.8$ & $77.4 \pm 11.8$ \\
\hline & $30 \mathrm{mg} / \mathrm{kg}$ & $944.6 \pm 34.3^{c}$ & $51.8 \pm 27.3$ & $69.3 \pm 10.5$ \\
\hline & $60 \mathrm{mg} / \mathrm{kg}$ & $995.8 \pm 32.1^{\mathrm{c}}$ & $101.9 \pm 44.5$ & $99.0 \pm 22.3$ \\
\hline \multirow[t]{3}{*}{ Imipramine } & $40 \mathrm{mg} / \mathrm{kg}$ & $953.3 \pm 33.8^{c}$ & $80.9 \pm 39.4$ & $69.6 \pm 10.6$ \\
\hline & & $F_{(4,45)}=122.85$ & $F_{(4,45)}=0.38$ & $F_{(4,45)}=0.67$ \\
\hline & & $P<0.0001$ & $P=0.8230$ & $P=0.6166$ \\
\hline \multicolumn{5}{|c|}{ Hippocampus } \\
\hline \multicolumn{2}{|c|}{ Vehicle } & $506.4 \pm 26.0$ & $51.4 \pm 5.5$ & $41.7 \pm 2.0$ \\
\hline \multirow{3}{*}{ YH-200 } & 15 mg/kg & $499.0 \pm 35.9$ & $55.0 \pm 4.0$ & $41.9 \pm 2.0$ \\
\hline & $30 \mathrm{mg} / \mathrm{kg}$ & $485.2 \pm 30.6$ & $50.2 \pm 4.0$ & $41.9 \pm 3.0$ \\
\hline & $60 \mathrm{mg} / \mathrm{kg}$ & $490.0 \pm 20.1$ & $51.6 \pm 4.0$ & $40.2 \pm 3.0$ \\
\hline \multirow[t]{3}{*}{ Imipramine } & $40 \mathrm{mg} / \mathrm{kg}$ & $491.2 \pm 39.3$ & $58.2 \pm 7.0$ & $42.9 \pm 4.0$ \\
\hline & & $F_{(4,45)}=0.07$ & $F_{(4,45)}=0.40$ & $F_{(4,45)}=0.11$ \\
\hline & & $P=0.9902$ & $P=0.8073$ & $P=0.89766$ \\
\hline \multicolumn{5}{|l|}{ Striatum } \\
\hline \multicolumn{2}{|l|}{ Vehicle } & $235.4 \pm 7.0$ & $5782.5 \pm 314.1$ & $1173.0 \pm 85.0$ \\
\hline \multirow[t]{3}{*}{ YH-200 } & $15 \mathrm{mg} / \mathrm{kg}$ & $262.7 \pm 29.7$ & $6367.5 \pm 536.3$ & $1129.4 \pm 97.8$ \\
\hline & $30 \mathrm{mg} / \mathrm{kg}$ & $285.1 \pm 14.2$ & $5626.6 \pm 263.6$ & $1024.0 \pm 54.6$ \\
\hline & $60 \mathrm{mg} / \mathrm{kg}$ & $321.5 \pm 18.5^{b}$ & $5718.4 \pm 315.4$ & $1088.1 \pm 63.5$ \\
\hline \multirow[t]{3}{*}{ Imipramine } & $40 \mathrm{mg} / \mathrm{kg}$ & $338.4 \pm 24.1^{\mathrm{c}}$ & $6148.8 \pm 379.5$ & $1170.5 \pm 73.9$ \\
\hline & & $F_{(4,45)}=4.32$ & $F_{(4,45)}=0.71$ & $F_{(4,45)}=0.67$ \\
\hline & & $P=0.0048$ & $P=0.5886$ & $P=0.6179$ \\
\hline \multicolumn{5}{|c|}{ Hypothalamus } \\
\hline \multicolumn{2}{|c|}{ Vehicle } & $2391.6 \pm 158.5$ & $296.3 \pm 17.9$ & $190.9 \pm 16.7$ \\
\hline \multirow[t]{3}{*}{ YH-200 } & 15 mg/kg & $2412.1 \pm 98.2$ & $373.8 \pm 73.4$ & $240.3 \pm 33.8$ \\
\hline & $30 \mathrm{mg} / \mathrm{kg}$ & $2395.1 \pm 129.0$ & $324.1 \pm 32.8$ & $218.5 \pm 12.3$ \\
\hline & $60 \mathrm{mg} / \mathrm{kg}$ & $2405.8 \pm 117.6$ & $340.7 \pm 36.6$ & $205.7 \pm 21.5$ \\
\hline \multirow[t]{3}{*}{ Imipramine } & $40 \mathrm{mg} / \mathrm{kg}$ & $2221.2 \pm 107.6$ & $359.5 \pm 31.0$ & $205.0 \pm 16.0$ \\
\hline & & $F_{(4,45)}=0.43$ & $F_{(4,45)}=0.50$ & $F_{(4,45)}=0.36$ \\
\hline & & $P=0.7891$ & $P=0.7349$ & $P=0.8376$ \\
\hline
\end{tabular}

${ }^{\mathrm{b}} P<0.05,{ }^{\mathrm{c}} P<0.01$ vs control group. $n=10 /$ group.
YH-200 $60 \mathrm{mg} / \mathrm{kg}$; $P<0.01$ for imipramine $40 \mathrm{mg} / \mathrm{kg}$ ) but did not influence the DA and DOPAC levels.

\section{Chronic (14 d) treatment of $\mathrm{YH}-200$ did not reveal drug resistance}

As shown in Figure 5A, 14-d administration of YH-200 significantly reduced the immobility time even at the lower dose of $30 \mathrm{mg} \cdot \mathrm{kg}^{-1} \cdot \mathrm{d}^{-1}$ and the $60 \mathrm{mg} \cdot \mathrm{kg}^{-1} \cdot \mathrm{d}^{-1}$ dose $\left(F_{(2,27)}=17.85\right.$, $P<0.0001)$ in the FST. However, there were no significant differences in body weight among all groups (Figure 5B).
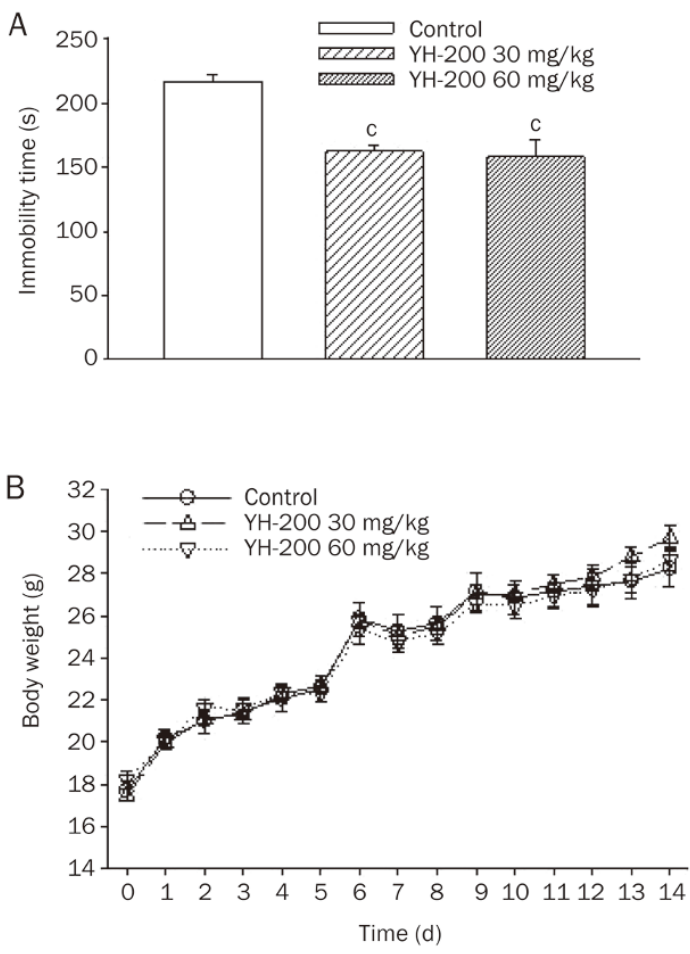

Figure 5. Effects of administration of $\mathrm{YH}-200$ for $14 \mathrm{~d}$ on immobility time in the mouse FST (A) and body weight variation (B). Values are expressed as the mean \pm SEM. ${ }^{\mathrm{C}} P<0.01$ vs control group. $n=10 /$ group.

\section{Discussion}

The Porsolt forced swimming test, which is also known as the behavioral despair model, is a primary screening test for antidepressants ${ }^{[9,14]}$. The basic idea of this model is that the coadministration of the test drug with specific receptor agonists or antagonists could be used to elucidate the mechanism of drug action ${ }^{[15]}$. The present study confirmed the antidepressant-like effect of YH-200 in the FST and TST. The oral administration of $\mathrm{YH}-200$ exerted a significant antidepressant-like effect after acute treatment in mice, and this activity was more potent than its derivative tetrandrine. In addition, it is worth noting that 14-d administration of $\mathrm{YH}-200$ did not develop drug resistance but instead revealed a more potent antidepressant effect at a lower dose than with acute treatment. In contrast to its BBI derivative tetrandrine, which has been reported to have a $\mathrm{LD}_{50}$ value of $646 \mathrm{mg} / \mathrm{kg}(\mathrm{ig})^{[16]}$, the $\mathrm{LD}_{50}$ value of 
YH-200 was higher than $1 \mathrm{~g} / \mathrm{kg}$ in rats (ig). These data suggested that YH-200 may be a safer and more potent antidepressant than tetrandrine.

The monoaminergic system is one of the most important targets in the pathophysiology and treatment of depression ${ }^{[17,18]}$. In this study, the antidepressant-like effect elicited by YH-200 was reversed by pretreatment with $\mathrm{SCH} 23390$ (a dopamine $\mathrm{D}_{1} / \mathrm{D}_{5}$ receptor antagonist), haloperidol (a dopamine $\mathrm{D}_{2} /$ $\mathrm{D}_{3}$ antagonist), prazosin (an $\mathrm{a}_{1}$-adrenoceptor antagonist), propranolol (a non-selective $\beta$-adrenoceptor antagonist) and NBQX (an AMPA receptor antagonist), but was augmented by yohimbine (an $\mathrm{a}_{2}$-adrenoceptor antagonist).

Depression is associated with hypofunction of the noradrenergic system ${ }^{[19]}$, and there is substantial preclinical and clinical evidence that NE plays a key role in the etiology of depressive disorders ${ }^{[20-22]}$. Moreover, $\mathrm{a}_{1}$ and $\mathrm{a}_{2}$-adrenoceptors have been shown to underlie some of the antidepressant-like effects of drugs observed in behavioral models of depression ${ }^{[23,24]}$. In addition, the inhibition of $a_{1}$ adrenoceptor mimics a depressive state, which, similar to chronic stress, is associated with $\mathrm{a}_{1}$ desensitization ${ }^{[25]}$. Furthermore, chronic antidepressant treatment gradually downregulates $\mathrm{a}_{2}$-adrenoceptor autoreceptors and their level is elevated both in depressed patients and by long term stress ${ }^{[26]}$. In pharmacological doses, yohimbine is not exclusively selective for the $a_{2}$ receptor, as it has been reported to bind with moderate or weak affinity to other receptors in vitro, such as $\mathrm{D}_{2}, \mathrm{a}_{1}$, and $5-\mathrm{HT}_{1 \mathrm{~A}}$ receptors, albeit with 5- to 10-fold lower affinity ${ }^{[27]}$. However, in tracer concentrations, yohimbine is highly selective for $\mathrm{a}_{2}$ sites in vivo. Yohimbine can produce an excessive release of NE by antagonizing presynaptic $\mathrm{a}_{2}$-adrenoceptors ${ }^{[28]}$. The data obtained in this study indicated that the NE contents in the prefrontal cortex and striatum were significantly elevated by YH-200. These results indicated that the NE-elevating activities of $\mathrm{YH}-200$ and yohimbine may underlie the augmentative effect of yohimbine on $\mathrm{YH}-200$ in the FST.

In addition, $\beta$-adrenoceptors seem to play a role in the mechanism of antidepressant therapies. Isoproterenol, which is a non-selective $\beta$-adrenoceptor agonist, caused an antidepressant-like effect. This effect of centrally administered isoproterenol was similar to the effects produced by the administration of proven antidepressant drugs. Propranolol antagonized the effect of centrally administered isoproterenol, which suggested that the antidepressant-like effect of this agonist was mediated by beta adrenergic receptors ${ }^{[29]}$. In the present study, pre-treatment with prazosin and propranolol was able to block the antidepressant-like effect of YH-200. These results suggested that the antidepressant-like effect of YH-200 in the FST may be dependent on the activation of postsynaptic $a_{1}$ - and $\beta$-adrenoceptors.

Dopamine receptors are divided into two groups, depending on their pharmacological and structural properties: the $D_{1}$-like dopamine receptors $\left(D_{1}\right.$ and $\left.D_{5}\right)$ and the $D_{2}$-like dopamine receptors $\left(D_{2}, D_{3}\right.$, and $\left.D_{4}\right)$. The dopaminergic system is strongly implicated in the regulation of $\operatorname{mood}^{[30]}$. A deficiency of mesolimbic dopamine is a leading candidate for the etiol- ogy of certain symptoms of depression (eg, anhedonia and loss of motivation $\left.{ }^{[31]}\right)$. Several previous reports have suggested that depression may often be accompanied by a relative hypodopaminergic state and that some DA receptor agonists have beneficial effects in the treatment of refractory and bipolar depression $^{[32]}$. In addition to involvement in the pathophysiology of depression, dopaminergic neurotransmission is known to mediate the effects of antidepressants. It has been reported that the potentiation of dopaminergic neurotransmission induced by chronic antidepressant treatments might contribute to their therapeutic effect ${ }^{[33]}$. In humans, this role was confirmed by the benefit of adding DA receptor agonists to standard antidepressants for treating resistant depression ${ }^{[34]}$. As shown in Figure 2, the dopamine $D_{1} / D_{5}$ receptor antagonist SCH23390 and the dopamine $\mathrm{D}_{2} / \mathrm{D}_{3}$ receptor antagonist haloperidol reversed the antidepressant effect elicited by $\mathrm{YH}-200$. This result indicated that $D_{1} / D_{5}$ and $D_{2} / D_{3}$ receptors might play a role in the antidepressant-like effect elicited by $\mathrm{YH}-200$. Moreover, it has been reported that dopamine $D_{2} / D_{3}$ receptor stimulation is required for the rapid antidepressant-like effects of ketamine ${ }^{[35]}$. Thus, it should be hypothesized that YH-200 may rapidly exert its antidepressant effect.

Evidence from postmortem and in vivo brain imaging studies has implicated amino acid neurotransmitter systems in the pathophysiology of major depressive disorder ${ }^{[36]}$. A fast (within $2 \mathrm{~h}$ ), robust, and relatively sustained antidepressant effect (lasting one to two weeks) was found after the infusion of ketamine in patients with treatment-resistant major depres$\operatorname{sion}^{[37]}$. There is emerging evidence that ketamine's antidepressant properties rely on increased AMPA signaling and rapidly induced synaptogenesis ${ }^{[38]}$. However, ketamine has the potential of drug abuse and has been associated with cognitive impairments and alterations in brain imaging measures when abused for prolonged periods of time ${ }^{[39]}$. In addition, it is well known that ketamine has a short systemic half-life and is extensively metabolized in the liver, which results in a high first-pass effect and thus makes the drug unsuitable for oral delivery. Interestingly, studies have demonstrated that AMPA receptor agonists may also produce antidepressant effects ${ }^{[40,41]}$. Thus, the development of promising novel agents that target the AMPA receptor is currently possible. The data obtained in the present study showed that the AMPA receptor may be involved in the antidepressive effects of $\mathrm{YH}$-200; further, it could be presumed that $\mathrm{YH}-200$ has rapid onset potential in treating depression patients. Interestingly, the AMPA receptor antagonist DNQX abolished the anti-immobility effect of ketamine in the TST, in agreement with reports in the literature that showed a similar effect using NBQX, but did not affect the anti-immobility effect of fluoxetine ${ }^{[42]}$. From these results, it could be presumed that $\mathrm{YH}-200$ may perform its anti-depressant effect as quickly as ketamine. In addition, this finding suggests that the antidepressant mechanism of YH-200 is different from that of fluoxetine.

Many researchers pay attention to the search for new compounds and treatment strategies for depression that could improve conventional therapies by utilizing multiple targets, 
and natural product structure modifications are alternatives for the development of antidepressants with reduced or no adverse effects. The results presented herein demonstrated for the first time that $\mathrm{YH}-200$ is able to produce an antidepressantlike effect. Moreover, the antidepressant-like effect of YH-200 seems to be mediated by an interaction with multi-targets including noradrenergic ( $\alpha_{1}, \alpha_{2}$, and $\beta$ receptors), dopaminergic $\left(D_{1} / D_{5}\right.$ and $D_{2} / D_{3}$ receptors) and AMPAergic (AMPA receptor) systems. However, the direct actions of YH-200 with these receptors should be unraveled. Furthermore, pharmacokinetic interactions cannot be completely ruled out at present. Further studies, including clinical trials with depressed patients, will be necessary to determine whether YH-200 produces similar therapeutic efficacy, as observed in the mouse behavioral tests in the present study.

\section{Acknowledgements}

This study was funded by grants from the National Natural Science Foundation of China (No 81173031, 81202511, and 81302746).

\section{Author contribution}

Yong-he ZHANG conceived and designed the experiments; Ya-ping XU, Jin-zhi SONG, Hui DING, Zhi-ge LIN, and Guang YANG isolated natural product; Yong-he ZHANG synthesized YH-200 and analyzed its structure; Zhao-fu SHENG, Sheng-Jie LI, Yuan-li HUANG, and Qing CAO performed the experiments; Zhao-fu SHENG, Bin YU, Xue-qiong ZHANG, and Suying CUI conducted the data analysis; Zhao-fu SHENG and Xiang-yu CUI wrote the first-draft manuscript and Yong-he ZHANG revised the manuscript.

\section{References}

1 Feder A, Nestler EJ, Charney DS. Psychobiology and molecular genetics of resilience. Nat Rev Neurosci 2009; 10: 446-57.

2 Nestler EJ, Barrot M, DiLeone RJ, Eisch AJ, Gold SJ, Monteggia LM. Neurobiology of depression. Neuron 2002; 34: 13-25.

3 Páez-Pereda M. New drug targets in the signaling pathways activated by antidepressants. Prog Neuropsychopharmacol Biol Psychiatry 2005; 29: 1010-6.

4 Millan MJ. On 'polypharmacy' and multi-target agents, complementary strategies for improving the treatment of depression: a comparative appraisal. Int J Neuropsychopharmacol 2013; 17: 1009-37.

5 O'Leary OF, Dinan TG, Cryan JF. Faster, better, stronger: towards new antidepressant therapeutic strategies. Eur J Pharmacol 2015; 753: 32-50.

6 Demyttenaere K. Agomelatine: a narrative review. Eur Neuropsychopharmacol 2011; 21 Suppl 4: S703-9.

7 Protais P, Arbaoui J, Bakkali EH, Bermejo A, Cortes D. Effects of various isoquinoline alkaloids on in vitro ${ }^{3} \mathrm{H}$-dopamine uptake by rat striatal synaptosomes. J Nat Prod 1995; 58: 1475-84.

8 Semwal DK, Semwal RB, Vermaak I, Viljoen A. From arrow poison to herbal medicine - the ethnobotanical, phytochemical and pharmacological significance of Cissampelos (Menispermaceae). J Ethnopharmacol 2014; 155: 1011-28.

9 Porsolt RD, Bertin A, Jalfre M. Behavioral despair in mice: a primary screening test for antidepressants. Arch Int Pharmacodyn Ther 1977; 229: 327-36.
10 Gundersen BB, Blendy JA. Effects of the histone deacetylase inhibitor sodium butyrate in models of depression and anxiety. Neuropharmacology 2009; 57: 67-74.

11 Steru L, Chermat R, Thierry B, Simon P. The tail suspension test: a new method for screening antidepressants in mice. Psychopharmacology (Berl) 1985; 85: 367-70.

12 Zhang Q, Yu YP, Ye YL, Zhang JT, Zhang WP, Wei EQ. Spatiotemporal properties of locomotor activity after administration of central nervous stimulants and sedatives in mice. Pharmacol Biochem Behav 2011; 97: $577-85$.

13 Wang ZJ, Zhang XQ, Cui XY, Cui SY, Yu B, Sheng ZF, et al. Glucocorticoid receptors in the locus coeruleus mediate sleep disorders caused by repeated corticosterone treatment. Sci Rep 2015; 5: 9442.

14 Castagné V, Moser P, Roux S, Porsolt RD. Rodent models of depression: forced swim and tail suspension behavioral despair tests in rats and mice. Curr Protoc Neurosci 2011; Chapter 8: Unit 8.10A.

15 Borsini F. Role of the serotonergic system in the forced swimming test. Neurosci Biobehav Rev 1995; 19: 377-95.

16 Chen Y, Chen M, Sun C, Li D. Study on acute toxicity of tetrandrine in male SD rats by intragastric administration. J Pract Med 2011; 27 : 24-5. Chinese.

17 Elhwuegi AS. Central monoamines and their role in major depression. Prog Neuropsychopharmacol Biol Psychiatry 2004; 28: 435-51.

18 Millan MJ. The role of monoamines in the actions of established and "novel" antidepressant agents: a critical review. Eur J Pharmacol 2004; 500: 371-84.

19 Brunello N, Mendlewicz J, Kasper S, Leonard B, Montgomery S, Nelson J, et al. The role of noradrenaline and selective noradrenaline reuptake inhibition in depression. Eur Neuropsychopharmacol 2002; 12: 461-75.

20 Leonard BE. The role of noradrenaline in depression: a review. J Psychopharmacol 1997; 11 Suppl 4: S39-47.

21 Brunello N, Blier P, Judd LL, Mendlewicz J, Nelson CJ, Souery D, et al. Noradrenaline in mood and anxiety disorders: basic and clinical studies. Int Clin Psychopharmacol 2003; 18: 191-202.

22 Nutt DJ. The role of dopamine and norepinephrine in depression and antidepressant treatment. J Clin Psychiatry 2006; 67 Suppl 6: 3-8.

23 Danysz W, Kostowski W, Kozak W, Hauptmann M. On the role of noradrenergic neurotransmission in the action of desipramine and amitriptyline in animal models of depression. Pol J Pharmacol Pharm 1986; 38: 285-98.

24 Kaster MP, Raupp I, Binfaré RW, Andreatini R, Rodrigues ALS. Antidepressant-like effect of lamotrigine in the mouse forced swimming test: evidence for the involvement of the noradrenergic system. Eur J Pharmacol 2007; 565: 119-24.

25 Stone EA, Lin Y, Quartermain D. Immobility from administration of the alpha1-adrenergic antagonist, terazosin, in the IVth ventricle in rats. Neurosci Lett 2003; 353: 231-3.

26 Flugge G, van Kampen M, Meyer H, Fuchs E. Alpha2A and alpha2Cadrenoceptor regulation in the brain: alpha2A changes persist after chronic stress. Eur J Neurosci 2003; 17: 917-28.

27 Millan MJ, Newman-Tancredi A, Audinot V, Cussac D, Lejeune F, Nicolas JP, et al. Agonist and antagonist actions of yohimbine as compared to fluparoxan at alpha(2)-adrenergic receptors (AR)s, serotonin $(5-\mathrm{HT})(1 \mathrm{~A}), 5-\mathrm{HT}(1 \mathrm{~B}), 5-\mathrm{HT}(1 \mathrm{D})$ and dopamine $\mathrm{D}(2)$ and $D(3)$ receptors. Significance for the modulation of frontocortical monoaminergic transmission and depressive states. Synapse 2000; 35: 79-95.

28 Goldberg MR, Robertson D. Yohimbine: a pharmacological probe for study of the alpha2-adrenoceptor. Pharmacol Rev 1983; 35: 143-80. 29 O'Donnell JM, Frith S, Wilkins J. Involvement of beta-1 and beta-2 
adrenergic receptors in the antidepressant-like effects of centrally administered isoproterenol. J Pharmacol Exp Ther 1994; 271: 246-54.

30 Dailly E, Chenu F, Renard CE, Bourin M. Dopamine, depression and antidepressants. Fundam Clin Pharmacol 2004; 18: 601-7.

31 Dunlop BW, Nemeroff CB. The role of dopamine in the pathophysiology of depression. Arch Gen Psychiatry 2007; 64: 327-37.

32 Takamura N, Nakagawa S, Masuda T, Boku S, Kato A, Song N, et al. The effect of dopamine on adult hippocampal neurogenesis. Prog Neuropsychopharmacol Biol Psychiatry 2014; 50: 116-24.

33 D'Aquila PS, Collu M, Gessa GL, Serra G. The role of dopamine in the mechanism of action of antidepressant drugs. Eur J Pharmacol 2000; 405: 365-73.

34 Takahashi H, Yoshida K, Higuchi H, Shimizu T, Inoue T, Koyama T. Addition of a dopamine agonist, cabergoline, to a serotoninnoradrenalin reuptake inhibitor, milnacipran as a therapeutic option in the treatment of refractory depression: two case reports. Clin Neuropharmacol 2003; 26: 230-2.

35 Li Y, Zhu ZR, Ou BC, Wang YQ, Tan ZB, Deng CM, et al. Dopamine $D_{2} / D_{3}$ but not dopamine $D_{1}$ receptors are involved in the rapid antidepressant-like effects of ketamine in the forced swim test. Behav Brain Res 2015; 279: 100-5.

36 Salvadore G, Singh JB. Ketamine as a fast acting antidepressant: current knowledge and open questions. CNS Neurosci Ther 2013;
19: 428-36.

37 Zarate CA Jr, Singh JB, Carlson PJ, Brutsche NE, Ameli R, Luckenbaugh $\mathrm{DA}$, et al. A randomized trial of an $\mathrm{N}$-methyl-D-aspartate antagonist in treatment-resistant major depression. Arch Gen Psychiatry 2006; 63: 856-64.

38 Machado-Vieira R, Salvadore G, DiazGranados N, Zarate CA. Ketamine and the next generation of antidepressants with a rapid onset of action. Pharmacol Ther 2009; 123: 143-50.

39 Lapidus KA, Soleimani L, Murrough JW. Novel glutamatergic drugs for the treatment of mood disorders. Neuropsychiatr Dis Treat 2013; 9: 1101-12.

40 Alt A, Nisenbaum ES, Bleakman D, Witkin JM. A role for AMPA receptors in mood disorders. Biochem Pharmacol 2006; 71: 127388.

41 Nations KR, Dogterom P, Bursi R, Schipper J, Greenwald S, Zraket D, et al. Examination of Org 26576, an AMPA receptor positive allosteric modulator, in patients diagnosed with major depressive disorder: an exploratory, randomized, double-blind, placebo-controlled trial. J Psychopharmacol 2012; 26: 1525-39.

42 Koike H, lijima M, Chaki S. Involvement of AMPA receptor in both the rapid and sustained antidepressant-like effects of ketamine in animal models of depression. Behav Brain Res 2011; 224: 107-11. 